\title{
Publisher Correction: Measuring progress from nationally determined contributions to mid-century strategies
}

Gokul lyer, Catherine Ledna, Leon Clarke, James Edmonds, Haewon McJeon, Page Kyle and James H Williams

Correction to: Nature Climate Change https://doi.org/10.1038/s41558-017-0005-9 (2017); published online 13 November 2017.

In the version of this Article previously published, technical problems led to the wrong summary appearing on the homepage, and an incorrect Supplementary Information file being uploaded. Both errors have now been corrected.

Published online: 21 November 2017

https://doi.org/10.1038/s41558-017-0027-3

\section{Publisher Correction: The price of fast fashion}

Correction to: Nature Climate Change https://doi.org/10.1038/s41558-017-0058-9, published online 2 January 2018.

In the version of this Editorial originally published, the rate of clothing disposal to landfill was incorrectly given as 'one rubbish truck per day'; it should have read 'one rubbish truck per second'. This has now been corrected in the online versions of the Editorial.

\section{Publisher Correction: A global synthesis of animal phenological responses to climate change}

Jeremy M. Cohen (D, Marc J. Lajeunesse and Jason R. Rohr

Correction to: Nature Climate Change https://doi.org/10.1038/s41558-018-0067-3, published online 5 February 2018.

In the PDF version of this Letter originally published, Fig. 3 was a duplicate of Fig. 1. This has now been corrected. The HTML version was unaffected. 